\title{
RELIEF OF FORFEITURE: EQUITY'S ANOMALOUS INTERVENTION FOLLOWING AN EVENT OF DEFAULT
}

\author{
Michael V Kokkinoftas*
}

\begin{abstract}
In the wake of the global financial crisis, borrowers found it increasingly challenging to obtain finance. Once credit had dried up, the pendulum swayed in favour of lenders during loan negotiations. In an effort to avoid and terminate unprofitable loan agreements, major banking institutions relied heavily on the punitive provisions that were set out in loan contracts, particularly the draconian material adverse change clause. Against this background, this paper analyses the material adverse change clause with particular reference to case law. It also examines defences that a borrower can seek to rely on in court, following the Turkish case of Cukurova Finance. The paper considers the doctrine of relief of forfeiture in the context of loan agreements and argues that it is a remedy a borrower should seek to raise in court. The doctrine permits a borrower to mitigate the severity of punitive clauses when an event of default is triggered.
\end{abstract}

\section{A. INTRODUCTION}

A loan agreement contains numerous provisions that are incorporated by a bank in order to safeguard the lender's position upon the borrower's insolvency. It 'excludes' the banks' exposure to a borrower who may become unable or unwilling to pay back the capital and interest under the loan. ${ }^{1}$ One example is the material adverse change (MAC) clause. A MAC clause permits the lender to suspend or terminate the facility agreement if there is an adverse change to the borrower's circumstances. It exists as a 'sweeping-up' clause, to predict future problems, and to provide the lender with a wide scope of authority to call in the loan and demand repayment. ${ }^{2}$ In the UK, lenders will have discretion in whether they call in the loan, ${ }^{3}$ since a 'default notice' and demand will usually be required to be made in terms of all the documentation that was provided under the loan. ${ }^{4}$ As a result, it is justifiably the most contested clause in the loan agreement.

This paper will begin by examining MAC clauses (Part B). It will thereafter outline the case law that upholds the orthodox position that following an event of default, there is 'no room

\footnotetext{
${ }^{*}$ Michael V Kokkinoftas (LLB, LLM, LPC Candidate). I am indebted to Professor Dan Prentice for his ideas and Professor Nigel Clayton for our intellectually stimulating discussions and his support at undergraduate level. All legal interpretations and any errors expressed in this essay reflect my own views of the law and do not represent the interpretations of any other person.

${ }^{1}$ Mark Hapgood, Paget's Law of Banking (13th edn, LexisNexis Butterworths 2007) 826.

${ }^{2}$ Ryan H Reade, 'Defaults and Remedies under International Bank Loan Agreements with Foreign Sovereign Borrowers - a New York Lawyer's Perspective’ (1982) 1 u III 1 Rev 89.

${ }^{3}$ Richard Youard, 'Default in international loan agreements - Part 1' (1986) JBL 276, 277.

${ }^{4}$ Peter Ellinger, Eva Lomnicka and Christopher Hare, Ellinger's Modern Banking Law (5th edn, OUP 2011$) 57$.
} 
for equity to intervene in international banking contracts ${ }^{5}$ to defend a borrower (Part C). This is set out in the cases of Grupo Hotelero Urvasco, ${ }^{6}$ IBP Inc, ${ }^{7}$ The Angelic Star ${ }^{8}$ and BNP Paribas $v$ Yukos Oil. ${ }^{9}$ The paper will further argue that following the decisions in Concord Trust $^{10}$ and Cukurova, ${ }^{\mathbf{1 1}}$ courts have incorporated the property doctrine of relief of forfeiture in the context of loan agreements (Part D). Although Cukurova is not legally binding, this paper considers the case as persuasive. The decision is also of interest as it offers direction as to how the courts may approach setting the amount of compensation that will need to be returned to the borrower, if the doctrine is awarded to a borrower. The paper will thereafter examine the defences put forward by Zakrzewski and Winsor with regards to the test of reasonableness, specified in the Unfair Contracts Terms Act 1977 (Part E). It will be argued that these are weak solutions in comparison to relief of forfeiture, since the main hurdle would be establishing that both the borrower and lender did not 'rely on their own intelligence' 12 and did not anticipate the risks that a MAC clause would derive. The paper will conclude by arguing that a loophole has arisen that effectively permits equity to intervene in loan contracts when a borrower is able to remedy a default.

\section{B. THE MATERIAL ADVERSE CHANGE CLAUSE}

Chakrabarti and Brierley set out an example of the MAC clause as, 'any event or series of events, which in the opinion of the Majority Lenders, is reasonably likely to have a material adverse effect [or change] on the business or financial condition of any member of the [borrowing company] or the [future] ability of any [borrower] to perform its obligations under any finance document. ${ }^{, 13}$ Operating as an all-encompassing clause, the MAC clause provides the loan agreement with 'teeth'. Its aim is to intimidate the borrower, '[acting] best in terrorem. ${ }^{14}$ One may state that the clause aims to determine any unforeseen events that may occur to a borrower (usually of a financial nature) which may legally satisfy when a bank can

\footnotetext{
${ }^{5}$ Burmah Oil Ltd v Governor and Company of the Bank of England (1979) 3 All ER 700.

${ }^{6}$ [2013] EWHC 1039.

${ }^{7}$ [2001] 789 A2d 14 [Del Ch].

8 [1988] 1 Lloyds Rep 122.

9 [2005] All ER (D) 281.

${ }^{10}$ [2005] UKHL 27.

11 [2013] UKPC 2.

12 [2010] EWCA Civ 1221169.

13 Arnondo Chakrabarti and Laura Brierley, 'The MAC clause: protection from the storm?' (2009) 24(8) BJIB\&FL 451, 452.

${ }^{14}$ Robert Cranston, 'Remedies in International Finance: Why So Few Formal Legal Proceedings' (1989) 4(2) JIBL 65, 67.
} 
terminate the loan. ${ }^{15}$ Once a MAC clause is triggered, the aftermath could prove to be grievous as financial stability and trust between the parties is broken. The default cuts the strings attaching the credit to the borrower and leaves the debtor in uncharted waters as he searches for foreign capital in an attempt to pay back the creditor. There will be no obligation on behalf of the lender to generate more capital or 'exonerate good money after bad' to the borrower. ${ }^{16}$ Hence, the clause is purposely envisioned to be absolute by tipping the pendulum and bargaining power in favour of the bank.

In order to mitigate risk and maximise protection for the lender, Youard highlights the importance of prudence when drafting a MAC clause. In his view, the purpose of a MAC clause is to 'specify the circumstances in which the lender can [lawfully] ask for immediate repayment' of the outstanding capital, before the predicted date of maturity of the loan agreement. ${ }^{17}$ During negotiations, the creditor's solicitors will identify all notable concerns that the lender has regarding any events of default and the clause will be drafted with these in mind. In contrast, the borrower's solicitors will attempt to mitigate the wide-ranging scope of the MAC clause. In order to appreciate the scope of the clause, the following section looks at the criteria that need to be fulfilled in the three elements of 'Material', 'Adverse', and 'Change'.

\section{Material}

The first criterion, the material, is outlined as a 'long-term and substantial' 18 impact, since a 'temporary change [or after-effect] in a borrower's circumstances is unlikely to be treated as material' or important. ${ }^{19}$ In Levison v Farin, it was held that the 'scale of impact necessary for a material adverse change to be called, was a $20 \%$ fall in the value of a company's assets. ${ }^{20}$ For instance, Zarkzewski clarifies that for a change to be material, it must simply ' [affect] the borrower's ability to repay, or significantly increase the risks assumed by the lender'. ${ }^{21}$ This broadens the scope of what can amount to material. In order for the adverse effect to be regarded as material, all circumstances and facts must be prudently measured, since the more precise the clause is about what changes will be of a significant nature, the easier it will be for the creditor to rely on the clause. ${ }^{22}$ However, it is the lender who must prove that this impairs

\footnotetext{
${ }^{15}$ Levison v Farin (1978) 2 All ER 1149.

16 [2013] EWHC 1039, 336.

${ }^{17}$ Richard Youard, Default in international loan agreements - Part 1' (1986) JBL 276, 277.

18 IBP, Inc v Tyson (2001) LEXIS 81 (Del Chanc).

${ }^{19}$ Jo Windsor, 'When can a material adverse change clause be relied on?' (2013) BJIB\&FL 28, 36.

${ }^{20}$ [1978] 2 All ER 11493.

${ }^{21}$ [2013] EWHC 1039 356; Rafal Zakrzewski, 'Material Adverse Change and Material Adverse Effect Provisions: Construction and Application' (2011) 5(5) LFMR 344, 352

22 Chakrabarti and Brierley (n 13) 454.
} 
the borrower's ability to perform its commitments and repay the loan. Unlike the borrower, the lender has secured his position by incorporating a MAC clause into an agreement, since it provides scope to terminate the agreement based on a subjective belief that the borrower's financial condition has deteriorated.

\section{Adverse}

The second criterion is that the change must be 'adverse' in nature and contrary to the lender's initial forecasts when the loan was negotiated. This usually involves the borrower's financial stability. Zakrzewski suggests reference to the Oxford English Dictionary to appreciate the scope of this word which defines adverse as: 'opposing any one's real or supposed interests [or expectations]; hence an unfavourable, hurtful, detrimental, injurious, calamitous, [or] afflictive'. ${ }^{23}$ The majority of lenders' reasonable view is that an adverse effect must be detrimental in order for it to trigger an immediate event of default. The default will be decided by exercising the lenders subjective judgment of what constitutes a calamitous effect on the borrower's circumstances, which increases the scope of the lender's security against the borrower.

\section{Change}

The third requirement that must be established is that there has been a degree of 'change'. A change can be defined as a variation or a sequence of anomalies in the circumstances or dealings of the borrower, which merit the termination of a loan agreement. The key variation will usually concern, but not limited to, the commercial dealings and financial wellbeing of the borrower. In order for the clause to be triggered, the degree of change must prevent a borrower or his/her business's ability to pay back the creditor, due to an exacerbating degree of variation in circumstances.

\section{THE ORTHODOX POSITION}

It is trite law in the UK that there is no envisioned room for a borrower to rely on equity to intervene in strictly negotiated banking agreements. ${ }^{24}$ The Supreme Court in Burmah Oil ${ }^{25}$ held that the parties to an agreement are bound by the strict contractual interpretation of the terms that they agreed to in the contract. In this case, the claimant could not undermine or set aside the loan based on it being 'unconscionable and inequitable'. ${ }^{26}$ This verifies the weight the

\footnotetext{
${ }^{23}$ Zakrzewski (n 21) [352].

${ }^{24}$ Burmah Oil (n 5).

25 ibid.

26 ibid.
} 
courts place on contractual terms and how they will rank above any dogma of good faith. Similarly, the argument that a loan agreement should be set aside due to it being unconscionable was rejected in Multiservice Bookbinding Ltd v Marden. ${ }^{27}$ Here, the courts held that a literal approach would be used when interpreting the terms of the loan and so there would be no room for equity to intervene. In contrast, under New York law, the courts seem to take a more generous stance. In Eighth Avenue, ${ }^{28}$ the courts endorsed a requirement upon the creditor to act in good faith in order to prevent the oppressive and 'harsh [nature]'29 that an acceleration clause may convey on a borrower. ${ }^{30}$

\section{Grupo Hotelero Urvasco}

In Grupo Hotelero Urvasco SA v Carey Value Added S. the court shed light on the orthodox position and the construction of the MAC clause. ${ }^{31}$ The Spanish hotel company and borrower, Grupo Hotelero Urvasco (GHU) issued a claim against Carey Value Added SL (Carey) for failing to advance funding under the loan agreement in 2008 following the sharp deterioration in the property market in Spain. GHU claimed that starving the development of funding at a time of tight credit caused the ultimate demise of the project. ${ }^{32}$ The loss of profits, therefore, amounted to a breach of obligations that Carey had consented to under the agreement. As a result, GHU maintained that the defendant should be liable to pay damages for an unwarranted acceleration. Carey counter-claimed that GHU had defaulted within the terms of the loan agreement when the work on the structure of the building ceased and it failed to make payment of the interest due. Reference was made to Gardiner \& Theobald's due diligence report which proved GHU's deteriorating position. ${ }^{33}$ The creditor considered that since GHU was near insolvency, it was not required to extend their risk and resume more money under the facility agreement to the borrower. Therefore, Carey demanded a repayment of $€ 55.4$ million. In order to ascertain whether a financial deterioration had occurred, Blaire $\mathrm{J}$ turned to the construal of what the financial condition of the company encompassed when the agreement had been set up. The claimant argued that:

[a]s a matter of ordinary language, financial condition does not encompass other matters such as future prospects of a company or external economic or market changes. Where

\footnotetext{
27 [1979] Ch 84.

284 AD 2d 754164 NYS 2d 812 [1957].

${ }^{29} 100$ Eighth Avenue Corporation v Morgenstern (1957) 4 AD 2d 754 (NYS).

${ }^{30}$ The requirement of good faith has also been codified under section 1-304 of the Uniform Commercial Code.

${ }^{31}$ [2013] EWHC 1039.

32 ibid [3].

33 ibid [109].
} 
a material adverse change clause is intended to extend to such matters, then these will

be expressly stated in the clause. ${ }^{34}$

This reinforced the judgment in Multiservice Bookbinding, ${ }^{35}$ which indicated that courts will base their interpretation of a MAC clause on the literal connotation of what is stipulated in the clause. The financial condition of the borrower would not incorporate volatile changes or trivial setbacks in the financial market.

As Grupo Hotelero ${ }^{36}$ has confirmed, 'there are no [UK] appellate decisions interpreting material adverse change clauses, and the few court trials that exist have failed to establish a consistent interpretation' of the degree of severity that the MAC entails. ${ }^{37}$ This disregards the 20 percent deteriorating financial threshold that was set out above in Levison v Farin ${ }^{38}$ and the courts' attempt to construe what would amount to a MAC. Equally, it also proves that a MAC clause should not be overly specific, since 'it will lack its underlying purpose as a wide-ranging sweeping-up clause if it starts to resemble a financial covenant'. 39

\section{IBP inc v Tyson Foods}

Merger and acquisition agreements in the US typically contain MAC clauses with respect to business assets and shares. The buyers insist on agreements that provide them with maximum flexibility to terminate the agreement prior to completion, alleviating the risk by placing it on the other party. ${ }^{40}$ The Delaware Court of Chancery interprets MAC clauses as unique and 'sui generis, [since] it [very rarely finds] a material adverse change to have occurred' ${ }^{41}$ This indicates that the US adopts a considerably more liberal approach, as opposed to the UK, when construing the severity and weight of a MAC. The Delaware Court of Chancery held that IBP's deteriorating annual earnings of 64 percent, behind the comparable quarter in the year 2000 and the $\$ 60.4$ million accounting impairment charge amounted to a MAC. The court held that the MAC must be construed in the wider context 'over a commercially reasonable period' and measured in years, as opposed to weeks or months. ${ }^{42}$ In this case, a mere setback in earnings would not amount to a MAC, as IBP's net earnings and financial performance had inclinations

\footnotetext{
34 ibid [348].

35 [1979] Ch 84.

36 [2013] EWHC 1039.

37 ibid [335].

38 [1978] 2 All ER 1149.

${ }^{39}$ Chakrabarti and Brierly (n 13) 454.

40 Steven M Davidoff, 'It's Hard Out There for a Seller' (DealBook, 24 September 2008)

$<$ http://dealbook.nytimes.com/2008/09/24/its-hard-out-there-for-a-seller/? $\mathrm{r}=0$ > accessed 8 September 2016.

${ }^{41}$ Andrew A Schwarz, 'A "Standard Clause Analysis" of the Frustration Doctrine and Material Adverse Change Clause’ (2010) 57 UCLA L Rev 789.

42 ibid.
} 
to fluctuate. In order for a buyer to legally trigger the MAC clause, he would be required to evidence that the change was unknown and it would be detrimental in the long-term prospects of the target company. As a result, the Chancery court placed the burden of proof on the buyer to justify terminating the original agreement, based on the MAC clause and concluded that the MAC had not occurred. Consequently, IBP's application for specific performance was approved. $^{43}$

It appears that US courts occasionally adopt miscellaneous interpretations based on the individual facts of each case. In Pacheco v Cambridge Technology Partners, ${ }^{44}$ it was assumed that the deterioration in financial condition (such as stock-price and Cambridge's decline in total growth revenue from 20 percent to 7 percent), was irrelevant. It was held as a matter of law that this did not amount to a breach of the MAC clause because it only indicated the company's future prospects and not an overall deterioration of material nature. Hence, it was asserted that a decline in performance would need to entail a 'comparison [from] year-overyear'. ${ }^{45}$ This proves that it is more challenging to terminate an acquisition agreement in the US based on a small decline in net earnings, rather than in the context of a loan agreement in the UK

\section{The Angelic Star}

An unorthodox attempt to mitigate and challenge the scope of the MAC clause was made in case of The Angelic Star. ${ }^{46}$ The borrower disputed the banks acceleration and argued that the repayment on demand constituted an act in terrorem and a punitive clause, capriciously penalising the borrower and should therefore not be permitted. Donaldson J rejected the defence clarifying that 'the acceleration clause does not increase the contract-breaker's overall obligation. ${ }^{47}$ Moreover, the Court of Appeal held that 'it was not a penalty for a lender to request full repayment' ${ }^{48}$ of the capital under the loan, when the borrower breaches his obligations by failing to pay back an instalment. It would only amount to a penalty if additional interest was added to the capital requested, similar to an overdraft.

One may criticise that morality and fairness are disregarded in a financial context and replaced with the strict commercial and literal construction of what was agreed under the

\footnotetext{
43 [2001] 789 A2d 14 [Del Ch] 24.

44 [2000] 85 F Supp 2d 69 [D.Mass].

${ }^{45}$ Davis Polk \& Wardwell, 'Memorandum of Court decisions Interpreting MAE Provisions' 2.

${ }^{46}$ [1988] 1 Lloyds Rep 122.

${ }^{47}$ Hugh Beale, Chitty on Contracts (31st edition, Sweet \& Maxwell 2012) 26-187.

48 [1988] 1 Lloyds Rep 122-127.
} 
contract. There is no room for equity to intervene and remedy the contract-breaker. ${ }^{49}$ It is expected that the courts would in any case be reluctant to step away from precedent. It appears that lenders have safeguarded and strengthened their position. They have left very little scope for a borrower to remedy a default.

\section{BNP Paribas v Yukos}

The creditor's strong position was also illustrated in the Chancery Division, in BNP Paribas $v$ Yukos Oil. ${ }^{50}$ Here, a syndicate of thirteen banks advanced $\$ 473$ billion to the defendant. The loan agreement exhibited numerous examples in Clause 19, as to when an event of default could be triggered. ${ }^{51}$ In 2003, following an investigation into the defendant companies, a series of materially adverse events occurred. First, Yukos Oils' Chief Executive Officer was arrested. This triggered the MAC clause and the event of default provision under Clause 19.27 of the loan. Second, the CEO resigned and the Russian Ministry of Tax fined the defendant company $\$ 3.3$ billion. Third, Standard \& Poor downgraded Yukos' credit rating and its assets were frozen. As a result, the loans under the agreement became due. Yukos Oil argued that the notice of the event of default was damaging to the Group and that in reality, the claimants stood to benefit from the 'wrongful act', 52 triggering the default. Evans-Lombe J rejected the claimant's submission and held that there was no reasonable prospect that Yukos could prove that BNP Paribas had relied on unreasonable information, which benefited them to terminate the contract. He referred to the dicta held by LJ Cockburn in Stirling $v$ Maitland,${ }^{53}$ that 'if a party enters into an arrangement which can only take effect by continuance of a certain existing set of circumstances, there is an implied engagement on his part that he shall do nothing of his own motive to put an end to that state of circumstances under which the engagement can be operative'. ${ }^{54}$ The claimants argued that the material adverse effect should be considered on the 'business, condition or production or export capacity of the Group taken as a whole'. ${ }^{55}$ The defendants claimed that although the borrower faced financial difficulties, it had not affected the capacity of the Group as a whole. Hence, they disputed the MAC despite Yukos filing for a US bankruptcy petition and defaulting on its payment of interest. The Chancery division applied the Stirling principle and held that in order for the event of default to constitute a breach

\footnotetext{
${ }^{49}$ Burmah Oil (n 5).

${ }^{50}$ [2005] All ER (D) 281.

51 ibid [8].

52 [2005] EWHC 1321 (Ch) [15].

53 [1864] 122 ER 1043.

54 [2005] All ER (D) 281 [22-3].

55 [2005] All ER (D) 281 [7].
} 
of contract, the defendant would need to prove that there was an implied term in the loan agreement, in which the bank had agreed not to accelerate. ${ }^{56}$ As such, the banks succeeded in their claim and were entitled to demand full repayment of the money. The case of BNP Paribas cemented the orthodox position that there was no room for equity to intervene in contractual loan agreements to remedy a breach. This proves that more often than not, the pendulum swings in favour of the creditor in the UK, especially when the borrower is bound by stringent terms under a loan agreement.

\section{RELIEF OF FORFEITURE}

This section explores two notable cases where courts have incorporated the property doctrine of relief of forfeiture in the context of loan agreements. As will be explored below courts have begun to move away from a traditional orthodox position as discussed above. Relief of forfeiture is a doctrine found in land law, which is obtainable only by court order. It is defined as a 'remedy only available to a mortgagee, [when] the mortgagor loses its rights, so that the mortgagee becomes the absolute legal or equitable owner of the assets. ${ }^{57}$ On this element of property law, Gray and Gray ${ }^{58}$ provide further clarification: 'the right to re-enter the demised premises and forfeit the lease or tenancy is the most draconian weapon in the armoury of the landlord, whose tenant has committed a breach of covenant. ${ }^{59}$ In a parallel manner, the creditor is entitled to terminate the loan agreement when an event of default has occurred. It is demonstrated that the courts have equitable jurisdiction to provide relief and the "power to reinstate [a] lease, where it is just and equitable to do so, provided that the tenant pays all the rent owed to and costs incurred by the landlord. ${ }^{60}$ This is complemented by statute in the Common Law Procedures Act 1852, where statutory protection is offered to a tenant. It is stipulated that a tenant is permitted to have legal proceedings postponed if he can pay the rental arrears, before the date of the judgment, 'six months after possession has been made.' ${ }^{61}$ Alternatively, the court can grant the identical protection provided by statute, by seeking equitable discretion via the doctrine of relief against forfeiture. This averts the tenant's penalty if he is able to pay all the arrears within six months of the landlord's possession. In Barton Thompson \& Co Ltd $v$ Stapling Machines $C o,{ }^{62}$ relief was granted by the courts when the

\footnotetext{
${ }^{56}$ BNP Paribas v Yukos Oil [2005] All ER (D) 281 [22].

${ }^{57}$ Louise Gullifer and Jennifer Payne, 'Corporate Finance Law - Principles and Policy' (1st edn, OUP 2011) 282.

${ }^{58}$ Gray and Gray, 'Elements of Land Law' (5th edn, OUP 2009).

59 ibid [4.4.2].

${ }^{60}$ [2005] UKHL 27 [39-40].

${ }^{61}$ Common Law Procedures Act 1852, s 210.

62 [1966] Ch 499.
} 
'tenant [produced] realistic evidence of his ability to pay off arrears of rent during the fixed period within the immediate foreseeable future. ${ }^{63}$

\section{Concord Trust}

In Concord Trust $v$ The Law Debenture Trust Corporation Plc, ${ }^{64}$ Elektrim BV, a subsidiary of the guarantor company Elektrim SA, issued several Eurobonds. Condition 12 of the bond agreement specified that under the events of default clause, one of the requirements was that Elektrim SA had to "perform or observe" 65 the obligations made by the bondholders. Condition 12 also set out that a failure to observe these obligations would not amount to an event of default, unless the failure was 'materially prejudicial to the interests of the bondholders' ${ }^{66}$ The main issue in this case was whether the suspension of the nominee, Mr Rymaszewski, constituted an event of default under Condition 10(d), and whether the Trustee's failure to accelerate was unlawful. An important term of the bond agreement was that all material decisions were to be decided taking into account the verdict of all the bondholders. Lord Scott of Foscote expressed that although the Trustee held discretionary powers, ' $30 \%$ of the bondholders [had] requested [that] the Trustee take action ${ }^{67}$ and accelerate. One argument that was raised considered the effect that a dishonest acceleration would make the Trustee liable for conspiring with the bondholders, as this would cause Elektrim 'injury by unlawful means'. ${ }^{68}$ The court rejected the argument as fanciful and unarguable. ${ }^{69}$ Drawing an analogy to property law, Lord Scott in obiter dictum, took a conflicting view to Lord Denning's judgment in TC Trustees Ltd v JS Darwen (Successors) Ltd.$^{70} \mathrm{He}$ emphasised that '[a] landlord, in the bona fide belief that his tenant has committed a breach of covenant, may give notice to the tenant to remedy the believed breach. If the notice is not complied with, then he may serve a forfeiture notice and institute proceedings for possession. The tenant can challenge the forfeiture and deny that any breach of covenant has occurred. This challenge may succeed. ${ }^{71}$ Hence, the Trustee was obliged to respect both Clauses 10 and 12 and demand repayment, because the suspension of the nominee was considered a material and detrimental matter. Concord ${ }^{72}$ proves that courts will construe a clause within its context and that it is to be obeyed based on its literal

\footnotetext{
63 ibid.

64 [2005] UKHL 27.

65 ibid 6.

66 ibid.

67 ibid 4.

68 ibid 39.

${ }^{69}$ ibid.

${ }^{70}$ [1969] QB 295.

71 [2005] UKHL 27, 39.

72 [2005] UKHL 27.
} 
interpretation. The fact that the Trustee regarded the clause as draconian and not 'materially prejudicial ${ }^{73}$ was irrelevant. There was no contractual breach or tortious duty of care that was owed by the Trustee.

Contrary to the orthodox position of Burmah $\mathrm{Oill}^{74}$ this suggests that equity does indeed have the power to intervene in strictly agreed contractual agreements. Nonetheless, it is debatable whether Lord Scott was aware in $\operatorname{Concord}^{75}$ that this would amount to a loophole for a borrower to seek relief and challenge the acceleration as was the case in Cukurova, where the borrower was seeking relief and challenged the acceleration. In the author's view, Concord was the catalyst that invited the marvels of equity and the doctrines of property law to act in unison and intervene in an attempt to soften the rigidities of contract agreements when there is an event of default or, when the borrower breaches a MAC clause.

\section{Cukurova Finance}

The much-anticipated Privy Council appeal concerned the Turkish conglomerate, Cukurova Group's (including its telecom subsidiaries Cukurova Finance International (CFI) and Cukurova Holding's (CH)) application to petition the Court of Appeal's decision of the Eastern Caribbean Supreme Court. The key issue disputed was whether the lender, Alfa Telecom Turkey Ltd (ATT) had been entitled to accelerate and demand immediate repayment, since the MAC provision had been breached. Perhaps more importantly, it was disputed whether Cukurova Group was entitled to relief from forfeiture. In other words, whether there was any room for equity to intervene in international loan agreements to mitigate the severity of a MAC provision. In order to answer this question, it is vital to examine the facts of the case by considering the drafting of the clause and how it applies to the facts.

In September 2005, ATT and the Cukurova Group entered into a facility agreement, where ATT accepted to lend its subsidiary, CFI, $\$ 1.352$ billion, which was secured as collateral on shares in the subsidiary companies. An unsecured facility of $\$ 355$ million was also advanced to $\mathrm{CFI}$ at a later date. Amongst several obligations stipulated under the facility agreement, clause 16.4 obliged the Cukurova Group to obey all actions '[ATT] may reasonably request for the purpose of perfecting the security'. ${ }^{76}$ Clause 17 recorded seventeen sub-headings with potential 'events of default'. It also set out the MAC provision, which established that '[a]ny event or circumstance which in the opinion of [ATT] has had or is reasonably likely to have a

\footnotetext{
73 ibid 13.

74 (1979) 3 All ER 700.

75 [2005] UKHL 27.

76 ibid 10.
} 
material adverse effect on the financial condition, assets or business of [CFI]' would permit ATT to accelerate and terminate the loan. ${ }^{77}$ In effect, the MAC clause was to be construed using the subjective judgment of the creditor. This offered the lender wide-ranging scope to terminate the loan based on an opinion, as opposed to something more concrete such as financial data. Whether the court had objectively established the existence of the event of default was irrelevant. ${ }^{78}$ The lending arrangement was an equally attractive transaction for ATT. The lender secretly predicted an event of default by Cukurova Group, since it knew that the subsidiary companies would be unable to pay back the interest. Bannister $\mathbf{J}$ affirmed this and held that the defendant's commercial aim had been to adopt the ownership of the borrower's collateral, as it attempted to 'starve [the company] of funds and blocked the payment of dividends of $\mathrm{CTH}{ }^{79}$ to challenge the claimant in an effort to force them to default. In 2007, the Geneva Group faced severe complications when telecommunications company, Sonera issued a press release that it had been awarded 52.91 percent holding in TCH following an arbitration award, which amounted to $\$ 3.1$ million. ATT sent the claimant a letter alleging that the Cukurova Group was in financial difficulty, as sixteen events of default had been breached under the facility agreement. An immediate acceleration and demand for repayment of the capital and interest was made, as well as a claim to be registered as the sole owners of the charged shares in the subsidiary companies. ATT later held a press conference which recorded Cukurova's deteriorating financial state in order to 'cast [the company] in a bad light as [much as] possible to make it difficult for them to raise [secondary] finance' 80 to pay off its debts. The borrower argued that this was an attempt to deter any other companies from advancing money on the shares. This spurred ATT to appropriate the charged shares, declaring that it was entitled to do so under the terms of the loan agreement. CFI sent a formal notice eight days later to ATT that it had the ability to repay the defendant the contractual interest, however ATT refused, claiming that it was too late. Following the precedent set out in Concord, the subsidiary companies began proceedings in an attempt to redeem their shares and oblige ATT to accept the repayment in order to discharge the loan.

\footnotetext{
77 ibid 12.

${ }^{78}$ One may suggest that during negotiations, a borrower should examine the lender's decisions, and request documentation or a list as to what the lender regards as trivial. In doing so, the borrower could prevent an absurd result and gain leverage during the negotiations.

${ }^{79}$ [2005] UKHL 27, 13.

80 ibid 25.
} 


\section{a) Court Proceedings}

The High Court considered whether there had been a legitimate event of default and if so, whether ATT could legally appropriate the shares. Bannister J who heard the arguments held that all sixteen of the alleged events of default were unsuccessful. It was held that even if the defendant had failed to justify the appropriation of the shares, because of its bad faith and improper motive, it would not avail the claimant's argument. ${ }^{81}$ The claimant also raised the doctrine of relief of forfeiture. Bannister $\mathrm{J}$ brushed over the argument and held that it was unnecessary to consider as the defendant was obliged to return the shares. The Court of Appeal reversed the High Court decision and held that three events of default had in fact occurred. ${ }^{82}$ It did, however, agree with the High Court that any improper motive on behalf of the defendant would not benefit the claimants. ${ }^{83}$ As such, it was held that ATT was entitled to appropriate the charged shares and upheld ATT's appeal. The subsidiary companies appealed, arguing that no event of default had in fact occurred. In the event it had, however, the claimants should be entitled to relief from forfeiture since the appropriation of the shares was vitiated on bad faith. ${ }^{84}$ Bannister $\mathrm{J}$ followed the High Court and reaffirmed in obiter dictum that ATT entered into the facility agreement and its associated instruments in the expectation that $\mathrm{CH}$ and $\mathrm{CFI}$ would default, with the intention of gaining shareholder control of Turkcell. ${ }^{85}$ Nonetheless, it was rejected as under contract law, ATT was entitled to terminate the loan based on their subjective opinion that a MAC had occurred. The critical question turned to whether the courts had the prerequisite jurisdiction to grant the claimant relief of forfeiture, considering that the repayment of the loan to ATT was secured by equitable mortgages over the charged shares in Turkcell. In Shiloh Spinners Ltd $v$ Harding ${ }^{86}$ Lord Wilberforce held that it is trite law that equity has always asserted 'the right to relieve against the forfeiture of property'. ${ }^{87}$ The jurisdiction was not confined to any particular type of case and the commonest instances concerned mortgages, or where the forfeiture was, in the nature of a penalty. ${ }^{88}$ As such, it can be submitted that Cukurova developed the role of the equitable doctrine that was suggested in Concord, ${ }^{89}$ as prior to this case, the property doctrine had not been considered before. Hence, it provided equity with a

\footnotetext{
${ }^{81}$ [2005] UKHL 27, 9.

82 ibid.

83 ibid.

84 ibid 10.

85 ibid 15.

86 [1973] AC 691.

87 [2013] UKPC 2, 116.

88 ibid 88.

${ }^{89}$ [2005] UKHL 27.
} 
wider scope to intervene in international loan agreements, where property was used as collateral and to offer the borrower a second chance to rectify the contract. As revealed in Peachy v Duke of Somerset, ${ }^{90}$ where it is possible to assert that the object of the transaction and of the insertion of the right to forfeit is to secure the payment of money, equity has been willing to relieve on terms that the payment is made with interest. ${ }^{91}$ As such, the claimants stated that there was sufficient precedent, which illustrated that it was possible for equity to intervene and soften the consequences of an event of default following a MAC clause.

Section 146(2) of the Law and Property Act 1925 also sets out that a court has the authority and discretion to grant or reject relief if notice of the breach has been provided, as well as a reasonable time thereafter to remedy the breach if it is achievable of being remedied. However, an issue that arose was whether the courts had jurisdiction to relieve the claimants in this case as it concerned shares; intangible property under a commercial agreement, as opposed to proprietary or personal rights under a contractual agreement. The courts held that there was no basis or authority to draw such a discrepancy, relying on the dicta affirmed by Dillion LJ in BICC plc $v$ Burndy Corporation..$^{92}$ They explained that it was necessary to be entirely "certain' 93 about the transaction and to consider other detailed factors regarding the default, such as 'the gravity of the breaches, the disparity between the value of the property of which forfeiture is claimed as compared with the damage caused by the breach.' ${ }^{94}$ Nonetheless, it seems that whether a borrower can provide this remains at the judge's discretion. In Hyman $v$ Rose, ${ }^{95}$ Earl Loreburn LC elaborated on the level of discretion and held that the circumstances, including the conduct of the parties is to be considered by the court. ${ }^{96}$ As a result, Cozens-Hardy MR depicted the necessity for Cukurova to remedy the breaches alleged in the notice, and pay reasonable compensation for the breaches which could not be remedied. ${ }^{97}$ Since the Cukurova Group had the ability to repay ATT, the Board held that the claimant should be entitled to relief from forfeiture.

\section{b) Implications}

Cukurova marks the first major deviation from a traditionally strict contractual approach. Previously, courts had routinely been in favour of banks and in particular, the terms of the

\footnotetext{
90 [1721] 1 Stra 447.

91 ibid.

92 [1985] 1 All ER 417.

93 John McGhee, 'Snell's Equity' (32nd edn, Sweet \& Maxwell 2010) [13-015].

94 [2013] UKPC 2116.

95 [1912] AC 623.

96 [2013] UKPC 2, 121.

97 ibid 122.
} 
lending contract. A good example is illustrated by the orthodox approach taken in Bank Of New York Mellon, ${ }^{98}$ BNP Paribas, ${ }^{99}$ and Grupo Hotelero. ${ }^{100}$ If a borrower failed to keep up with repayments then this automatically amounted to a default. Following Cukurova, however, it is expected that the pendulum will swing more equally in court for both the borrower and the lender. This paper suggests that a borrower should now seek to raise the defence of relief from forfeiture or attempt to incorporate equitable relief as a term in the loan agreement, during the negotiating process. Today, a borrower should not be at the mercy of the lender if he is able to contend that he has the ability to pay back the money owed under the loan agreement. In parallel, it is advised that a lender should still seek to rely on the traditional contractual provisions such as financial covenants, representations and cross-default clauses. However, it is likely that this type of remedy has several limitations. There is no evidence to prove that Cukurova has actually sent shockwaves throughout the financial markets. For instance, in the situation where the borrower is utterly insolvent, there will be no room for relief of forfeiture, as it is unlikely that another lender will provide additional capital if its credit rating has suffered. It is also debatable whether this remedy was only based on the individual facts of Cukurova. It is yet to be seen whether the case will set a precedent in the UK. On the other hand, with the development and invasion of the property doctrine into a financial context, one may argue that it unseals the floodgates for other areas of law to also intervene, such as human rights law. ${ }^{101}$ What is clear, however, is that relief from forfeiture has provided a loophole for equity to interfere and soften the harsh and draconian aftermath of the event of default. It has the ability to mitigate the severity of a MAC clause when an event of default has been triggered or the loan has been hastily accelerated, leading to an unfair or illegal result.

\section{E. OTHER DEFENCES}

It is also important to explore other defences that an insolvent borrower should choose to consider in the event of a default. ${ }^{102}$ These could pertain to: (i) Section 3(2)(b) of the Unfair Contract Terms Act 1977; (ii) The similarities between MAC clauses and Force Majeure clauses; and (iii) Contractual Protections.

\footnotetext{
98 [2009] All ER (D) 155.

99 [2005] All ER (D) 281.

100 [2013] EWHC 1039.

101 Article 1 of the Protocol to the Convention for the Protection of Human Rights and Public Freedoms states that, no one shall be deprived of their possessions except in the public interest. It is not clear whether this would be a strong argument since one may argue that the monies received from a loan are not actually their possessions. 102 Zakrzewski (n 21) 359.
} 


\section{The Unfair Contract Terms Act 1977}

Zakrzewki states that a borrower should seek to rely on the Unfair Contract Terms Act 1977 (UCTA 1977) to mitigate the scope of the MAC clause. Section 3(2)(b) sets out that a borrower: cannot by reference to any contractual term claim to be entitled to: a) render a contractual performance substantially different from that which was reasonably expected of him, or b) render no performance at all, except in so far as the contract term satisfies the requirement of reasonableness. ${ }^{103}$

Zakrzewski clarifies this by stating that a written standard form suggests 'pre-printed contract forms or terms flashed up on a website rather than terms proffered by a party as a starting point for negotiations.' ${ }^{104}$ Once the standard form is satisfied, the borrower will still need to prove that the MAC clause does not fulfill the reasonableness condition. The borrower will also need to prove that the bank's termination of the loan agreement has in itself varied the contractual performance substantially from that which was reasonably expected of the borrower. However, this interpretation is questionable. The borrower would fail to satisfy that he is a consumer, able to invoke section 3(2)(b) of the UCTA 1977. ${ }^{105}$

An alternative viewpoint is set out by Winsor, who states that a court is more likely to construe the requirement by imposing the Wednesbury test of unreasonableness. ${ }^{106}$ This restricts lenders from arriving at a decision which no reasonable person in their position would have made. ${ }^{107}$ The distinction is that the Wednesbury test confers a higher threshold on the borrower to prove that the clause was unreasonable, rather than the suggested statutory reasonableness requirement under the UCTA 1977. It is maintained here that the tests of reasonableness are contradictory, since 'terms negotiated between commercial parties are [deemed to] satisfy the requirement of reasonableness' ${ }^{108}$ This is illustrated by the doctrine of contractual estoppel, which was established in the case of JP Morgan Chase Bank v Springwell Navigation Corporation. ${ }^{109}$ In this case, Springwell Navigation Corporation purchased 42 derivatives of rouble bonds from JP Chase Morgan Bank of GKO, which were issued by the

\footnotetext{
103 ibid.

104 ibid.

105 Section 3(2)(b)(2) states that a party cannot by reference to any contract term-(a) when himself in breach of contract, exclude or restrict any liability of his in respect of the breach; or (b) claim to be entitled-(i) to render a contractual performance substantially different from that which was reasonably expected of him, or (ii) in respect of the whole or any part of his contractual obligation, to render no performance at all, except in so far as (in any of the cases mentioned above in this subsection) the contract term satisfies the requirement of reasonableness.

${ }^{106}$ A decision is Wednesbury unreasonable if no reasonable person acting reasonably would have followed it: Associated Provincial Picture Houses Ltd v Wednesbury Corporation [1948] 1 KB 223.

107 Windsor (n 19).

108 Watford Electronics Ltd v Sanderson CFL Ltd [2001] 1 All ER.

109 [2010] 2 CLC 705.
} 
Ministry of Defence of the Russian Federation. As the GKOs were exchanged using US dollars, Springwell lost a significant amount of money due to currency fluctuations and raised the argument that there was a duty of care owed to Springwell and so a negligent misstatement had occurred. The Court of Appeal held that JP Morgan was not accountable; the bond agreement contained a clause which demonstrated that the investors were to rely on their own intelligence. ${ }^{110}$ Examining the test of reasonableness under section 3(2)(b) of UCTA 1977, the Court upheld the contractual freedom of the agreement. It also clarified that Springwell was considered an intellectual and experienced investor, aware of the risk hazards that the derivative bonds may bring. Thus, the exclusion clause was considered by the courts to be reasonable under UCTA 1977. Following Peekay Intermark Ltd v Australia, ${ }^{111}$ Springwell was contractually estopped from contending that he was induced into entering into the contractual arrangement to purchase the bonds. If a corporate entity is regarded as having the adequate experience of an intellectual investor, then it will be contractually estopped from disputing that it was induced into entering into the contract.

\section{Force Majeure Clause}

Zakrzewski's proposal that a borrower should claim that a MAC clause is in fact a force majeure clause is also questionable. ${ }^{112}$ Although he provides an innovative argument, it is unlikely that courts will find in favour of this based on the following reasons. First, Zakrzewski states that the function of A MAC clause is virtually identical to the nature of the force majeure clause and should be treated within the umbrella of the force majeure jurisprudence, because of the lack of case law in this area. ${ }^{113}$ Although the author agrees that both a force majeure and a MAC clause do share resemblances, the latter does not have an identical definition. For instance, Beale defines a force majeure clause as:

any contractual term by which one, or both of the parties is excused from performance of the contract, in whole or in part, or is entitled to suspend performance or to claim an extension of time for performance, upon the happening of a specified event beyond his control. $^{114}$

\footnotetext{
110 [2010] EWCA Civ 1221169.

111 [2006] 2 Lloyd's Rep 511.

112 A Force Majeure clause is a clause that permits a party to terminate the performance of its obligations when certain circumstances arise which are beyond their control.

${ }^{113}$ Rafal Zakrzewski, 'When is a material adverse change clause a force majeure clause?' (2012) 27(9) BJIB\&FL 547

${ }^{114}$ Beale (n 47) 14-137.
} 
Second, a MAC clause has certain limitations as opposed to the force majeure clause, which are set out within the wording of the clause. A MAC is intended to act as a sweeping up and all-encompassing provision to consider events that are within the power of the borrower to control and prevent additional risk, even if there is an exacerbating event to the borrower's circumstance. In contrast, a force majeure clause is intended to cover specific events that are outside of the control and responsibility of the borrower's power. ${ }^{115}$ For instance, this could include an act of God (extreme weather conditions or flooding), the on-going civil war in Syria, or the economic and political instability following Brexit. The international law firm Norton Rose has shed light on the correlation between political uncertainties and MAC. Using the banking system in Cyprus in 2012 as an example, Norton Rose clarified that the run on the banks would not trigger an adverse event of default, since this was a political, social, and economically driven force majeure in the financial markets. Although Zakrzewski acknowledges that a MAC clause has additional functions to a force majeure clause, he suggests 'adopting the jurisprudence that has developed around force majeure clauses' ${ }^{116}$ and applying this to MAC clauses. In the opinion of the author, it would be a misnomer to adopt this argument. The case law in this area would have to be disregarded, since commercially a MAC clause shifts the risks of harmful events or changes onto the borrower, whereas a force majeure clause only acts to excuse one of the party's obligations. ${ }^{117}$ Thus, the doctrine of strict liability still applies with reference to the MAC clause. In contrast, the doctrine does not apply when a force majeure clause has been stipulated in a contract, as there would be an element of debt relief or forgiveness for non-performance.

\section{Contractual Protections}

Alternatively, a borrower could ask the lender to apply an objective interpretation of what is meant by the term 'material'. As Gray states, a subjective construal provides with no legal certainty as to whether any given set of circumstances constitute a MAC. ${ }^{118}$ Nonetheless, this provides scope for the creditor to draw down the loan agreement when he chooses, which is why loan agreements generally employ a subjective test. ${ }^{119}$ In more extreme circumstances, a borrower may dispute that the bank wrongly accelerated, and attempt to sue for economic torts.

\footnotetext{
${ }^{115}$ Chitty on Contracts ( $\mathrm{4}$ 47) explains that a contract may be discharged on the ground of frustration when something occurs after the formation of the contract, which renders it impossible to fulfil the contract or transforms the obligation to perform into a radically different obligation from that undertaken during the formation of the contract.

116 Zakrzewski (n 113) 548.

117 ibid.

${ }^{118}$ Richard Gray, 'Does the Crisis Bring Default under MAC Clauses' (1998) 17 Int'1 Fin L Rev 17, 18.

119 Windsor (n 107).
} 
Although an incorrect acceleration will legally result in damages, it is suggested that the borrower should seek to challenge the lender's discretion, however unlikely, by applying contractual protections such as a de minimis threshold. It is a clause that endeavours to re-price the deal on a quarterly or yearly basis or impose a grace period, if the failure to pay the installment under the loan agreement is due to a technical error. Nevertheless, this depends on the individual facts of each case and the creditor's judgment. For example, a creditor must consider whether it is in his interests for the loan to continue in operation as the borrower's failure to meet the conditions of the loan may be the 'tip of the iceberg'. ${ }^{120}$ This would lead to further deliquesce in the borrower's financial condition.

It is hoped that this section will provide for a set of considerations to explore for future borrowers who have suffered events of default. Although the aforementioned defences may be criticised as feeble, they offer the borrower the opportunity to make the most of a difficult position. The author agrees with Zackrzewski that these defences 'would require rather exceptional circumstances to be established at trial'. ${ }^{121}$ Hence, the relief of forfeiture doctrine may be considered a more substantial defence for a borrower to challenge a bank in court. However, it remains to be seen whether the case of Cukurova was an exception to case law, decided on the basis of its facts, or whether it will be used by courts in future.

\section{F. CONCLUSION}

This paper has articulated the relevant cases and considered the property doctrine of relief from forfeiture. It has established that following Cukurova, the pendulum does not swing only in the direction of a lender. Now, it swings more equally to the borrower as well. It appears that equity will be able to intervene in a financial context when a MAC clause has occurred, effectively leading to an event of default. Focusing on equity's development throughout the common law, the paper has presented a case study of the orthodox position, placing particular focus on Concord and Cukurova. These two cases have ingeniously widened the liberty for equity to incorporate a property law doctrine and shield a defaulting borrower. In conclusion, it will be exciting to see how the MAC clauses will evolve, following the ensuing case law. It is expected that there is scope for equity to intervene and mitigate the severity of a material adverse change clause, when an event of default has been triggered following the intrusion of relief from forfeiture.

\footnotetext{
${ }^{120}$ Richard Youard, 'Default in international loan agreements - Part 2' (1986) JBL 379, 379.

${ }^{121}$ Zakrzewski (n 21) 359.
} 